\title{
SOFRIMENTO PSÍQUICO NA PERVERSÃO: O CASO DEXTER
}

\author{
Fábio Roberto Rodrigues Belo* \\ Larissa Bacelete
}

\begin{abstract}
RESUMO. A análise do personagem fictício Dexter permite construir hipóteses metapsicológicas sobre as origens da perversão. A posição perversa nesse caso deve-se à presença maciça de violência nas origens do sujeito psíquico. Dexter expressa o abandono sofrido pela atuação pulsional, os assassinatos em série, tentando inverter o estado de passividade no qual se encontra. Sua angústia pode ser organizada de duas formas distintas: a primeira é consciente, fornecida por seu pai, Harry, que o ensina a não deixar vestígios dos seus crimes. A segunda maneira é inconsciente, e traduz o desejo de submeter o outro à dor, fazendo com que, por meio do mecanismo de identificação projetiva, o perverso desfrute deste sofrimento que provoca, sendo remetido, então, às suas vivências originárias de submissão. Conclui-se que na perversão a angústia não apenas está presente, como também é constitutiva da escolha do sujeito de operar pela via da violência.
\end{abstract}

Palavras-chave: Perversão; angústia; violência.

\section{PSYCHIC SUFFERING IN PERVERSION: THE DEXTER AFFAIR}

\begin{abstract}
The analysis of the fictional character Dexter makes it possible to construct metapsychological hypotheses about the origins of perversion. The perverse position in this case is caused by the strong presence of violence at the psychic subject's origin. Dexter expresses the suffered abandonment by acting-out, the serial murders, trying to reverse the state of passivity in which he is. Dexter's anxiety can be organized in two distinct ways: The first is conscious, supported by his father, Harry, who teaches him how not to leave traces of his crimes. The second way is unconscious and translates the desire of subject the other to pain, allowing the perverse, through projective identification, to enjoy the suffering he causes, being remitted to his originary experiences of subjection. We conclude that in perversion, anxiety is not only present but is also constitutive of subject's choice to operate through the path of violence.
\end{abstract}

Key words: Perversion; anxiety; violence.

\section{EL SUFRIMIENTO PSIQQUICO EN LA PERVERSION: EL CASO DEXTER}

RESUMEN. El análisis del personaje ficticio Dexter permite la construcción de hipótesis metapsicológicas sobre los orígenes de la perversión. La posición perversa en este caso se debe a la presencia masiva de la violencia en los orígenes del sujeto psíquico. Dexter expresa el abandono sufrido a través de una actuación pulsional, los asesinatos en serie, intentando invertir el estado de pasividad en el que se encuentra. Su angustia puede ser organizada de dos maneras distintas: la primera es consciente, proporcionada por su padre, Harry, quien le enseña a no dejar rastros de sus crímenes. La segunda es inconsciente, y traduce el deseo de someter al otro al dolor, haciendo con que, a través del mecanismo de la identificación proyectiva, el perverso disfrute del sufrimiento que provoca, siendo remitido, así, a sus experiencias originarias de sumisión. Concluimos que, en la perversión, la angustia no sólo está presente, sino que es constitutiva de la elección del sujeto de operar por medio de la violencia.

Palabras-clave: Perversión; angustia; violencia.

\footnotetext{
Doutor em Estudos Literários (Literatura Brasileira), pela Universidade Federal de Minas Gerais. Professor Adjunto I, no Departamento de Psicologia, da Universidade Federal de Minas Gerais.

\# Mestra em Estudos Psicanalíticos pela Universidade Federal de Minas Gerais (2012), pesquisadora do Projeto CAVAS (UFMG).
} 
Nesse artigo, analisaremos o caso de Dexter, personagem da série homônima, lançada em outubro de 2006, nos Estados Unidos. Baseados no romance de Jeff Lindsay (2004), Darkly Dreaming Dexter, os 12 episódios que compõem a primeira temporada contam a história do analista forense Dexter Morgan, especialista em padrões de dispersão de sangue na Divisão de Homicídios do Departamento de Polícia de Miami. Filho adotivo de Harry, policial reconhecido por sua conduta impecável neste mesmo departamento, Dexter divide seu tempo entre o trabalho e outra atividade que executa compulsivamente: a procura de criminosos que não foram punidos pelo sistema judiciário, a comprovação da responsabilidade destes sujeitos nos respectivos crimes e seus subsequentes assassinatos.

Após cursar Medicina, Dexter torna-se perito na Homicídios, e seu trabalho consiste em avaliar, tanto em cenas de crime quanto por meio de exames laboratoriais, como os padrões de dispersão de sangue podem sugerir determinados tipos de ferimentos, uso de armas específicas, e até características físicas do(s) autor(es). Uma de suas frases mais repetidas é a de que "o sangue conta uma história".

Apesar de mostrar-se completamente à vontade em suas atividades, nota-se que Dexter escolhera este trabalho também como uma maneira de ter acesso a arquivos policiais (o que consegue mantendo uma amizade com a funcionária responsável por eles, para a qual sempre leva presentes), encontrando pessoas que cometeram repetidamente crimes que considera imperdoáveis - sempre envolvendo assassinato, cuja vítima é inocente -, podendo, então, prosseguir com sua atuação. Entretanto, a fim de não levantar suspeitas, Dexter se esforça para ser gentil, calmo e prestativo, mas também se mantém extremamente reservado no ambiente profissional.

O comportamento discreto de Dexter visa evitar chamar a atenção para si mesmo, evitando também que se levante qualquer suspeita sobre sua rotina, seus afazeres para além do trabalho, e sua vida íntima. Assim, não mantém qualquer ligação emocional intensa, seja no plano amoroso e sexual, ou mesmo familiar. É por isso que não cede às recorrentes tentativas de sedução de sua chefa, Ten. LaGuerta, e que não compartilha seus problemas com a irmã, filha legítima do casal Morgan, que trabalha como policial infiltrada. Contando sempre com o faro policial aguçado de Dexter, que parece tê-lo aprendido com o pai, Debra reclama muitas vezes da distância afetiva do irmão. Pelo mesmo motivo, o personagem assume um relacionamento com Rita, mulher traumatizada com os constantes maus-tratos do ex-marido, que se recusa a ter uma vida sexual com o namorado. A distância, e até mesmo certa formalidade que se observa entre o casal, são fatores apaziguadores para Dexter, que, desse modo, sente manter o controle da situação.

Sem dúvida, é somente com seu falecido pai que o personagem mantém uma ligação emocional intensa e complexa. Para Dexter, Harry era o único que o conhecia verdadeiramente, e tê-lo orientado sobre como direcionar seus impulsos agressivos foi determinante em sua vida, poupando-o de "ter assassinado várias pessoas na juventude, só para ver o sangue escorrer" (Dexter, temp. 1, ep. 3, 26:06 a 27:17). Figura extremamente idealizada, Harry encarna o objeto onipotente na vida psíquica de Dexter: excelente policial, homem honesto, marido dedicado, e, principalmente, o pai atencioso que foi capaz de identificar no filho adotivo traços mórbidos que as outras pessoas ignoravam, amando-o, apesar disso. Várias são as cenas nas quais a ligação entre os dois é mostrada, ainda durante a infância de Dexter, ou mesmo em sua adolescência. Escolhemos duas, ambas do primeiro episódio, para nos determos mais detalhadamente.

Na primeira cena (Dexter, temp. 1, ep. 1, 06:56 a 07:24), Dexter aparece com aproximadamente dez anos de idade, e seu pai o questiona sobre um cachorro da vizinhança, que desaparecera. Harry afirma ter encontrado uma cova com ossos enterrados, e a criança então justifica ter matado o animal por causa do barulho que fazia, incomodando sua mãe, que se encontrava muito doente. Harry prossegue: "Havia muitos ossos lá, Dexter. Não apenas os de Buddie". Na sequência da cena (21:45 a 22:22), Harry pergunta ao filho se ele já pensara em matar algo "maior que um cachorro, como, por exemplo, uma pessoa". $\mathrm{O}$ menino confirma, e o pai insiste, questionando por que não matara. Dexter responde que não o fizera por pensar que os pais não gostariam disso. $O$ que desejamos ressaltar aqui, mais do que o diálogo entre os dois, é a expressão do pai da criança, que, visivelmente assustado, tenta confortá-la.

Tal semblante também aparece na outra cena (temp. 1, ep. 1, 29:09 a 31:50) à qual nos reportaremos: já adolescente, Dexter é confrontado pelo pai, quando este encontra em seus pertences um conjunto de facas de caça, algumas ainda manchadas de sangue. O filho afirma que só mata animais, mas Harry sente que os impulsos violentos do garoto estão saindo de seu controle, ainda que tente conversar com ele sobre isso. Propõe então que canalizem esta violência, já que não podem interrompê-la. Vale a pena transcrever parte do diálogo, que começa com Harry interpelando Dexter:

- Filho, existem pessoas lá fora que fazem coisas muito ruins. Pessoas terríveis. E a 
polícia não consegue pegar todas elas... Entende o que estou dizendo?

- Está dizendo... que merecem morrer.

- Isso mesmo. Mas é claro que você tem que aprender a identificá-las, a cobrir seus rastros. Mas posso ensiná-lo.

- Pai...

- Tudo bem, Dex. Você não pôde evitar o que houve com você [referindo-se a experiências anteriores à sua adoção], mas pode tirar o melhor disso. (Dexter, temp. 1, ep. 1, 29:09 a 31:50 ).

Cabe aqui informar ao leitor que Dexter fora adotado aos três anos de idade e, embora Harry mencione algumas vezes que o filho teria tido experiências anteriores que influenciaram diretamente a construção de sua personalidade, quase nenhuma outra menção é feita às vivências da criança neste período. Não se sabe quem são seus pais biológicos, ou por que fora adotado. Mesmo a mãe adotiva de Dexter é lembrada poucas vezes, ficando claro apenas que morrera de câncer durante sua infância.

Nota-se que as recomendações de seu pai se tornam essenciais para Dexter, e passam a moldar suas interações no cenário social. Umas delas é a de que o filho "se encaixe", o que significa fazer de tudo para parecer o mais comum possível, sem atrair a atenção dos outros para seu comportamento. Pensando assim, Harry aconselha o personagem a se mostrar alegre e entusiasmado em programas familiares, mesmo que não esteja, a esquivar-se de qualquer tipo de violência no contexto escolar, para não ser visto como agressor, e até mesmo a tentar demonstrar interesse por meninas da sua idade, como a maioria de seus colegas. Estas orientações seriam maneiras de ajudar o filho a esconder "a escuridão" - segundo o termo de Harry que o habita, evitando que fique exposto e algum dia seja descoberto, responsabilizado e penalizado por seus crimes. Apesar de se revelarem medidas eficazes em termos práticos, percebemos que elas acabam por dar a Dexter a sensação de certa artificialidade em suas vivências sociais, distanciando-o das outras pessoas, e dificultando o acesso a seus próprios sentimentos. Pois, reprimindo os impulsos sádicos e as dificuldades que encontrava em estabelecer ligações afetivas com os outros, Harry não estava também privando o filho de seus conteúdos internos, e de buscar uma forma de lidar com essa destrutividade através da sublimação?

Talvez esta instrução - quase uma proibição tenha contribuído enormemente para a instauração de uma sensação de vazio psíquico, relatada por Dexter em diversos momentos, sensação essa que aparece sempre atrelada à sua percepção de que desconhece as regras de convivência com as outras pessoas e que não consegue compartilhar da dor ou da felicidade que demonstram sentir. Observamos, então, que o código Harry - expressão utilizada pelo próprio personagem - organiza seu psiquismo, determinando padrões de comportamento a serem seguidos, condutas aceitáveis e inaceitáveis, e até a escolha de suas vítimas. Sua atuação é organizada e meticulosa, baseada nos ensinamentos do pai, policial experiente, sobre como ocultar os vestígios dos assassinatos que comete.

Nesse ponto, parece-nos interessante esboçar para o leitor o cenário montado por Dexter no momento destas execuções, para que fiquem claros certos aspectos de sua dinâmica psíquica: ao definir onde matará a vítima, certifica-se de que não será interrompido durante a tarefa, e recobre todo o espaço interno do local com plástico, dispondo suas ferramentas de trabalho bem organizadas sobre uma banqueta, utilizando uma mesa ou cama para alocar sua presa, ainda viva, porém despida, e imobilizada pela ação de fortes tranquilizantes. Dessa maneira, Dexter pretende deixar o cenário exatamente como estava antes de sua chegada, sem qualquer pista ou sinal que possa identificá-lo. Outros elementos que insere neste espaço são as provas da autoria dos crimes cometidos por suas vítimas (geralmente fotos de cadáveres), e estas são então confrontadas com o material e obrigadas a confessarem seus feitos. Por fim, o personagem faz um pequeno corte no rosto de cada vítima, recolhendo uma gota de sangue, que será catalogada e guardada em sua casa. Quase sempre esfaqueia sua presa no coração, levando-a rapidamente à morte. Após o assassinato, o personagem esquarteja o corpo, colocando as partes em sacos que desova no oceano, usando o barco que possui.

Fica evidente, após essa descrição, o alto grau de organização com o qual pode operar seu psiquismo, tecendo um planejamento complexo de cada passo de seus atos agressivos. Esta constatação poderia levantar questionamentos sobre o caráter compulsivocompulsório da atuação do personagem: se ela é tão bem articulada, poderíamos, ainda assim, trabalhar com a hipótese de conteúdos inconscientes que impulsionam este comportamento?

Para Bonnet (2008), o perverso abriga elementos inconscientes resultantes da sedução originária que não foi suficientemente mediada pelo objeto, redundando na internalização de objetos perseguidores, que excitam e atacam o ego do sujeito, levando-o a responder a estas sensações através da violência. $\mathrm{O}$ desejo de submeter o outro à dor faz com que, por meio do mecanismo de identificação 
projetiva, o perverso desfrute deste sofrimento que provoca, sendo remetido às suas próprias angústias.

Essas angústias de desmoronamento egoico, de invasão, e de perseguição, são abordadas por Roussillon (1999), quando este trabalha a questão do traumatismo primário, que engendra uma patologia narcísica grave, cuja perversão pode ser apenas uma das formas de expressão. Por sua vez, acerca da atuação perversa, Bonnet salienta a pressão pulsional exercida pelas mensagens não-metabolizadas, enxertadas no sujeito pelo contato com o outro. No seriado, uma cena (temp. 1, ep. 6, 23: 56 a 26:00) ilustra muito bem esse estado de agonia. Nela, Dexter tem seu primeiro sonho de angústia, embora já esteja na idade adulta: seu pai aparece convidando-o a entrar em casa, para se abrigar de uma forte tempestade que se anuncia. Dentro do apartamento, Harry retira, ainda viva, a última vítima do filho, que cede lugar para que então este seja colocado na posição de dominado. Amarrado, como costuma fazer com aqueles que mata, Dexter vê a irmã assumir o papel de agressor, desempenhando seu ritual mortífero. Colhendo uma gota de seu sangue, Debra mostra-se desapontada por não ter conhecido antes a verdadeira identidade de Dexter. Neste momento, pede que este diga suas últimas palavras, o que ele não consegue fazer. Debra, por sua vez, não aparenta surpresa, afirmando que já esperava por essa reação do irmão. Acerta-o, então, com uma grande faca. Um dos aspectos relevantes do sonho é a parceria existente entre sua irmã e a figura de um assassino em série desconhecido ${ }^{2}$, que possui informações privilegiadas sobre o passado de Dexter.

Nessa cena, temos uma amostra das fantasias masoquistas que povoam o psiquismo do personagem. Dexter, cuja identidade assenta-se sobre a violência ritualizada, sobre a submissão do outro e o prazer dela extraído, se vê encurralado na armadilha preparada pelos que o cercam, e que conhecem, ou podem vir a conhecer seus impulsos agressivos. Mais uma vez, aparece a ideia de que não é permitido ao personagem partilhar seus estados internos e seus sentimentos, sem que isso tenha um desfecho trágico: ou sua verdade assusta e afasta os outros, ou eles se transformam em

2 "The Ice Truck Killer", como é chamado o autor dos assassinatos de várias prostitutas na periferia de Miami, cuja "assinatura" é a forma com que trata os corpos de suas vítimas: drena todo o sangue e dispõe as partes em algum local público de grande visibilidade, embrulhadas com bastante cuidado. Seu apelido se deve à suposição dos investigadores de que o assassino comete seus crimes em um caminhão refrigerado, usado para diminuir o fluxo sanguíneo das vítimas. Embora não seja revelada sua identidade, este personagem mantém uma estranha ligação com Dexter, deixando-lhe mensagens que sugerem seu conhecimento sobre a prática perversa deste último. objetos persecutórios e destrutivos, dispensando-lhe a violência que permeia suas atuações.

$\mathrm{O}$ fato de não conseguir exprimir suas últimas palavras, no final do sonho, não poderia ser interpretado como uma impossibilidade do personagem de traduzir em forma de pensamentos as mensagens enigmáticas que carrega, introduzindo-as no jogo simbólico? Ou seja, não seria a expressão da angústia de Dexter por se sentir condenado a lidar com esses conteúdos exclusivamente pela via da repetição?

Bonnet (2008) sugere que a fonte de maior sofrimento na perversão é uma quebra repentina na relação com o objeto primário, levando o sujeito, excitado pela ação deste, a encontrar, por si mesmo, uma maneira de dar vazão a essas pulsões. Dessa forma, a criança expressa o abandono sofrido pela atuação pulsional, tentando inverter o estado de passividade no qual se encontra. Quando o adulto não é capaz de proporcionar modos mais sublimados de operar a excitação que atingiu a criança, - seja por ter dispensado a ela um tratamento indiferente ou violento, ou por não ter podido estar presente - o infante pode estruturar seu psiquismo a partir de um desejo de vingança, impondo a outros objetos o sofrimento que experimentou. Pensamos que Dexter age dessa forma, ao dispensar às suas vitimas um julgamento tão rigoroso quanto o que recebia de Harry. Afinal, acreditar que o filho é habitado por uma violência extrema e incurável, é também condená-lo da pior maneira possível, negando a este sujeito o reconhecimento de outras facetas de sua personalidade, que poderiam ser valorizadas e desenvolvidas.

Notamos que o pai de Dexter reconhece seus impulsos violentos, buscando garantir sua segurança quando o ensina a dissimular a destrutividade. E embora se mostre empenhado na educação do filho, mantendo com o personagem uma postura protetora e amorosa, Harry parece identificar nele algo de irrecuperável, uma violência crua, quase instintiva, que não pode ser interrompida, transformada, elaborada - quando muito, pode ser canalizada. Tais interpretações das fantasias agressivas da criança o levam a retratá-la como uma espécie de monstro, ou aberração, que não tem outra saída a não ser esconderse sob um falso-self.

Isso nos leva a perceber que, certamente, Harry projeta conteúdos sádicos e disruptivos de seu próprio psiquismo, atribuindo-os à natureza do filho. Bonnet (2008) insiste muito nesta interpretação da perversão, seja quando aborda as manifestações perversas na infância ou resgata a noção de perversão transitória, cujo surgimento é comum na adolescência. Para o autor, se algum traço da sexualidade está sendo superinvestido, deve-se verificar quais mensagens 
estão fazendo-o eclodir, quais impedimentos de tradução ou de veiculação fantasmáticas ele sofre para ser atuado com tanta frequência. Esses conteúdos provêm sempre das vivências deste infante com os objetos primários, com a cota pulsional excessiva que estes direcionam ao psiquismo incipiente do sujeito. Portanto, para o autor, é necessário que a criança exteriorize essas mensagens não-decifradas. Bonnet traz ainda a interessante observação de que nem sempre apenas vítimas e algozes se encontram fixados em mecanismos de repetição compulsiva da cena traumática. Testemunhas, profissionais que lidam com esses casos diariamente, buscando um tipo de intervenção, também estão sujeitos a serem invadidos pelos elementos disruptivos dessa violência. Lembremos, então, que Harry exerceu o ofício de detetive policial durante muitos anos, e, apesar de sua reputação ética inabalável, em algumas cenas comenta com o filho sua frustração acerca da impunidade de alguns criminosos. Não estaria, assim, negando seus traços sádicos, em detrimento da identificação desses impulsos na conduta do filho?

Pensando na afirmativa de Bonnet, sobre o caráter traumático da ruptura da relação entre sujeito e objeto primário, podemos ressaltar ainda, como fator desencadeante de grande quantidade de angústia, o fato de seu pai ter sido a única pessoa com a qual Dexter foi capaz de se envolver emocionalmente, deixando-lhe, após seu falecimento, a sensação de que se encontrava totalmente desvinculado afetivamente das outras pessoas. $\mathrm{O}$ autor menciona que a atuação perversa pode também ter a função de tentar restabelecer o contato com esse objeto ausente, pois a repetição compulsiva conserva traços da ligação que existira entre a dupla. Ao que nos parece, Dexter encarna as projeções sádicas de Harry, e dessa forma mantém o contato com a sombra deste pai distante.

Bonnet (2008) discute esta dificuldade de partilhar sentimentos, pensamentos, que parte tanto do próprio perverso, que busca se isolar a fim de manter em segredo seus rituais compulsivos, quanto da sociedade, que tende a recusar toda espécie de ligação a estes sujeitos, considerando-os incapazes de experimentar qualquer emoção. Apesar dessa visão leiga sobre o perverso, o autor nos adverte que ele não ignora os afetos, mas age de maneira a projetá-los no objeto, buscando o controle dos mesmos pela via da dominação do outro. Sabemos que, pelo código transmitido por seu pai, Dexter mata outros assassinos que se mostram incapazes de domar seus impulsos violentos, e, desse modo, parece inverter sua sujeição em relação à própria atuação: são os outros, as vítimas do personagem, que não contêm suas pulsões, enquanto ele, seguidor de regras bem estabelecidas, acredita desse modo atingir o autocontrole. Podemos dizer, portanto, que, no psiquismo de Dexter, o afeto é confundido com o objeto, o ódio, a passividade, o caos, a desordem e a destrutividade devem ser eliminados, assim como os que cometem crimes que envolvem tais sentimentos.

Acreditamos que esse movimento de expulsar os elementos fragmentadores pode ser ilustrado na instigante cena (temp. 1, ep. 8, 36:34 a 39:54) na qual Dexter consulta um psiquiatra cuja conduta ética o intriga. Pesquisando sobre o trabalho do Dr. Meridian, o personagem desconfia que este tem um mórbido fascínio pelo estado depressivo de algumas de suas pacientes, contribuindo, de alguma forma, para o suicídio delas. Com o objetivo de testar sua teoria, Dexter se apresenta ao terapeuta como um homem frágil, sofrendo com problemas em seu relacionamento amoroso. Conta que tem certa resistência em se envolver afetivamente, escondendose sob uma aparência que não condiz com o que realmente é, e que não consegue ter relações sexuais com a namorada, temendo perder o controle da ligação que mantêm. É curioso notar que, ainda que o personagem tenha a intenção de desmascarar o psiquiatra, adotando uma identidade fictícia para se submeter ao tratamento, Dexter fala de várias questões que são fonte de sofrimento e angústia em sua vida real. Isto não indicaria que, em outras circunstâncias, algum trabalho terapêutico poderia ser empreendido, invalidando, portanto, a ideia de que nada modificaria seu estatuto de assassino em série? Mas, o ponto mais interessante da cena ainda nos parece outro: Dr. Meridian interpreta que o personagem não se envolve sexualmente com sua namorada pelo mesmo motivo que o leva a afastar as outras pessoas, ou seja, por medo de que elas não o aceitem como é. Sugere que, se essa defesa e suas causas não forem suficientemente analisadas, o paciente não conseguirá modificar esta situação. Propõe que Dexter participe de uma sessão de relaxamento, na qual tentará se lembrar de episódios nos quais se sentiu impotente, durante toda sua vida. Inicialmente, o personagem se nega a fazêlo, mas pouco a pouco, começam a surgir em sua mente flashes de cenas nas quais alguns colegas o intimidavam e o agrediam na adolescência; outras que mostram suas tentativas de vingança em direção a esses rapazes, sendo, porém, interrompidas e duramente reprimidas por seu pai; outras que se relacionavam ao assassino em série que parecia persegui-lo e saber sobre seu passado; e, finalmente, imagens que apresentam uma criança chorando, sentada numa poça de sangue. Bastante perturbado com estas lembranças, Dexter deixa o consultório subitamente.

Toda essa sequência ilustra a clivagem psíquica do personagem, e o contato com estes conteúdos se 
mostra excessivamente fragmentador. O que ocorre é que, para ele, sua prática sádica não está relacionada a estas fantasias e angústias masoquistas, pois isso demandaria um importante trabalho de reflexão e elaboração psíquica. A atuação funciona, então, como um mecanismo egossintônico, e, poderíamos até mesmo dizer, unificador de sua identidade, fazendo com que se sinta real e verdadeiro, em contraponto às suas impressões de artificialidade nas relações sociais. Quando o terapeuta solicita uma espécie de catarse do personagem, fazendo com que não apenas tente pensar nestes elementos que provocam descontrole emocional, mas também sinta esta sensação de passividade, Dexter não suporta fazer esta conexão, abandonando a sessão atordoado.

Esta questão da catarse também é levantada por Bonnet (2008), que acredita ser impensável qualquer sucesso terapêutico sem que a cota de afeto correspondente a esses fantasmas venha à tona. Cabe ainda dizer, sobre este ponto, que, nas temporadas seguintes do seriado, a capacidade elaborativa de Dexter aumenta, e, consequentemente, o número de assassinatos diminui, trazendo, porém, um aumento de angústia ao psiquismo do personagem, que já não recorre sempre ao ato para aliviar seus impulsos agressivos. Esse nos parece ser um sinal de evolução, tanto no que se refere ao modo com que ele se percebe, como o que consegue depreender do(s) objeto(s), já que a cisão é um dispositivo aplicado tanto interna quanto externamente. Assim, quanto mais integrado o psiquismo do personagem, e, portanto, menos baseado na divisão do ego, mais poderá entrar em contato com suas partes frágeis, com os aspectos criativos e construtivos de sua personalidade, e também com as contradições éticas e morais que habitam os outros, tornando-os objetos totais, complexos, repletos tanto de tendências destrutivas quanto positivas.

\section{HIPÓTESES SOBRE AS ORIGENS DA PERVERSÃO}

Podemos ver na relação entre Harry e Dexter um tipo de sedução designada por Roussillon (1999) de traumatismo primário: trata-se do trauma que conduz o sujeito a se relacionar com o meio externo a partir de uma transferência baseada na reversão, ou seja, imputando ao outro o que ele próprio não suporta experimentar, e que não pôde ser integrado ao seu psiquismo. $\mathrm{O}$ autor descreve os três tempos de formação deste trauma: no primeiro, o psiquismo incipiente da criança é atravessado por grande quantidade de excitação, a qual não consegue manejar com os recursos que possui nesse momento. No segundo tempo, inundado pela angústia e o desprazer decorrentes da impossibilidade de metabolizar estes conteúdos, o sujeito espera ser acolhido e apaziguado pelo objeto. Mas, se novamente ele se frustra neste processo, o ódio produzido leva ao terceiro tempo, instaurando o trauma primário propriamente dito. Este estado se caracteriza pela clivagem no ego, pela desestruturação do psiquismo, fazendo com que o sujeito se retire da experiência, afastando-se psiquicamente dela. É o que testemunhamos na história de nosso personagem, que sofrera um grave traumatismo no início de sua infância, cujas consequências tiveram bastante influência em sua constituição psíquica, mas não contou com acolhimento e alívio suficientes dessa agonia, sendo frequentemente convocado a revivê-la por meio da violência cometida com outros objetos. Portanto, seguindo a ótica de Roussillon (1999), a compulsão de Dexter a tirar a vida de outras pessoas deve ser

interpretada como uma defesa desse tipo de patologia narcísica.

Outra estratégia defensiva à qual o psiquismo do personagem parece recorrer é aquilo que Roussillon (1999) denomina neutralização energética: uma tentativa de evitar o retorno do material traumático, impossibilitando qualquer ligação afetiva que reative esses conteúdos, ou ainda, operando um rebaixamento emocional generalizado, a fim de prevenir este tipo de repetição. Já mencionamos como Dexter se esquiva de um relacionamento íntimo com seus familiares, seus colegas e até mesmo sua namorada, pensando que esse tipo de interação poderia trazer complicações ao seu estilo de vida, colocando em perigo seu segredo. Mas, além disso, ele também demonstra acreditar que, ao investir afetivamente um objeto, este não suportaria lidar com sua agressividade, abandonando-o tão logo os identificassem. Tal fantasia fica explícita em uma cena (temp. 1, ep. 8, 39:55 a 43:09), que se segue àquela que descrevemos anteriormente (temp. 1, ep. 8 , 36:34 a 39:54), na qual o personagem se sente muito angustiado durante uma sessão de terapia. As interpretações que recebe do psiquiatra, combinadas às lembranças de várias situações nas quais era subjugado, fazem com que o personagem finalmente deseje ter relações sexuais com Rita, ato muitas vezes adiado em decorrência de seus temores. Dexter se surpreende, então, quando a namorada explicita o desejo de recebê-lo em sua casa mais vezes, já que sua fantasia era a de que, conhecendo-o sem suas defesas, Rita só enxergaria seu "passageiro sombrio" (termo que usa para falar de sua compulsão).

Levantamos a hipótese de que essa construção fantasmática deriva da incapacidade do objeto primário em interpretar positivamente a agressividade do sujeito, admitindo seu potencial criativo. Winnicott 
(1939/2002) destaca a importância do desempenho da figura materna nas tentativas da criança de explorar a realidade exterior. Para o autor, o reconhecimento da distinção entre eu-outro é acompanhado de impulsos agressivos, como o morder, exemplo da mescla de excitação e agressão que origina a percepção das fronteiras entre sujeito e objeto. Isto significa que, para que esta diferenciação não seja debilitada, é necessário que o adulto suporte o quinhão de violência que a criança lhe dirige, ajudando-a a incluí-lo em processos construtivos.

Se é verdade, portanto, que o bebê tem uma grande capacidade para a destruição, não é menos verdadeiro que ele também tem uma grande capacidade para proteger o que ama de sua própria destrutividade, e a principal destruição existe sempre, necessariamente, em sua fantasia. E, quanto a essa agressividade instintiva, é importante assinalar que, embora se torne em breve algo que pode ser mobilizado a serviço do ódio, é originalmente uma parte do apetite, ou de alguma outra forma de amor instintivo. É algo que recrudesce durante a excitação, e seu exercício é sumamente agradável. (Winnicott, 1939/2002, p. 97)

Fica evidente, dessa maneira, a participação do objeto na transformação de impulsos agressivos dispersos em saídas integradas no ego, que suscitam movimentos construtivos. Winnicott (1939/2002) afirma que a descoberta da natureza exterior do objeto pelo infante acontece por meio de mudanças gradativas, que demandam certo tempo de maturação para lidar com aquilo que escapa ao seu controle. Quando a criança é acompanhada nesse desenvolvimento, podendo vivenciar de maneira saudável este processo, torna-se capaz de agredir e odiar, o que pode ser um sinal de progresso emocional. Essa agressividade pode ser balizada pelo sonhar, pelo fantasiar e pelo brincar. Segundo o autor, brincando o infante alcança o impulso construtivo, alternativa à simples destruição. Isso ocorre quando ele aceita a responsabilidade pelos elementos destrutivos de sua conduta.

Essa relação entre agressão e construção pode ser comprovada se retirarmos de uma criança (ou de um adulto) a oportunidade de fazer alguma coisa pelos que lhe são próximos e queridos, ou a possibilidade de "contribuir", de participar na satisfação das necessidades da família. Por "contribuir" entendo fazer coisas por prazer, ou ser como alguém, mas ao mesmo tempo verificando que isso é uma necessidade para a felicidade da mãe ou para o andamento do lar. É como

\begin{abstract}
“encontrar o próprio nicho". Uma criança participa fazendo de conta que cuida do bebê, arruma a cama, usa a máquina de lavar ou faz doces, e uma condição para que essa participação seja satisfatória é que esse fazde-conta seja levado a sério por alguém. Se alguém zomba, tudo se converte em pura mímica, e a criança experimenta uma sensação de impotência e inutilidade físicas. Então, facilmente poderá ocorrer uma explosão de franca destrutividade e agressão. (Winnicott, 1939/2002, p. 107-108, grifos nossos)
\end{abstract}

Neste trecho, Winnicott discute uma questão que podemos avaliar a partir da história de Dexter. A integração da destrutividade, convertendo estes impulsos originários da separação entre eu-outro em uma ação construtiva, está vinculada ao investimento, pelo adulto, em um comportamento do sujeito, reconhecendo sua relevância como uma tentativa de contribuir no ambiente em que vive. Sabemos que Harry buscava direcionar a violência do filho para o assassinato de alguns indivíduos que julgava merecedores disso, considerando essa atuação uma forma de tirar algum proveito desses elementos traumáticos presentes no psiquismo de Dexter. Mas, podemos dizer que esse pai colabora para o surgimento de um comportamento construtivo no infante, valorizando-o, conforme vimos na teoria winnicottiana? Para responder a esta pergunta, valemo-nos de uma cena (temp. 1, ep. 8, 13:39 a 14:33), em que, adolescente, Dexter surpreende o pai durante a noite, aplicando sobre Harry um de seus métodos para dominar as vítimas. O pai, então, reconhece que aquele fora um ótimo ponto de ataque, o que faz com que o filho se vanglorie de finalmente tê-lo superado na técnica. A fala de Harry é significativa: “Isso não é um jogo, Dexter! Não é para ser divertido. Acha que quero te ensinar estas coisas? Esta é a única maneira que conheço para te manter longe de uma cadeira elétrica." (temp. 1, ep. 1, [trecho temporal]).

Nota-se a ambiguidade com que Harry trata este comportamento do filho: se por um lado o classifica como produtivo, quase uma prestação de serviços no cenário social, por outro, não deixa de se horrorizar com o caráter violento desse modo de agir. Este aspecto fica bastante claro quando o personagem - já em outra temporada da série - rememora uma cena, na qual, ainda jovem, mostra ao pai o cadáver de sua primeira vítima, que teria sido indicada pelo próprio Harry. Ainda inexperiente, não consegue executar a tarefa com o asseio recomendado pelo pai. Este, quando se depara com a grande quantidade de sangue e as partes esquartejadas do corpo apresentado pelo 
filho, sente-se extremamente enojado, deixando o local imediatamente. Dexter não compreende o motivo da reprovação paterna, já que o planejamento do assassinato fora acompanhado e incentivado por Harry.

Assim, é perceptível que essa tarefa de integrar a destrutividade no ego do sujeito fica completamente prejudicada na relação entre o personagem e seu pai. A mediação desses impulsos agressivos exercida pelo adulto parece fracassar na medida em que tais processos estão envoltos numa atuação que não deixa de evocar em Harry os conteúdos mais angustiantes e fragmentadores.

Roussillon (2004) nos lembra que, de acordo com a teoria winnicottiana, é a função de espelho do objeto primário, refletindo para o bebê seus próprios conteúdos internos, que irá instaurar nele a capacidade de distinção entre percepção e representação do objeto. Em outras palavras, nos momentos de construção do psiquismo infantil, a mãe realiza um trabalho de imitação de seu bebê, de seus afetos e sensações, pontuando-os, inserindo entonações vocais, expressões faciais e interpretações, que auxiliam a criança a simbolizar estas experiências e, posteriormente, reconhecer-se como sujeito, dentro de um eu circunscrito às fronteiras egoicas. Estas projeções maternas na superfície corporal da criança propiciam a distinção entre eu-outro no aparelho mental do bebê, e as excitações nele depositadas podem seguir a via da representação, ou seja, ser recalcadas, produzindo fantasias. Entretanto, quando essa atividade não é desempenhada de modo satisfatório pelo objeto, ocorre a fragilização da organização narcísica primária, e os limites entre os elementos internos e externos são comprometidos. Segundo Roussillon, a perversão pode funcionar como uma solução para as angústias advindas deste tipo de sofrimento narcísico, elegendo uma prática que escoe a excitação que não pôde ser circunscrita pelo processo de simbolização empreendido pelo objeto. Assim, a saída pela compulsão se sobrepõe aos modos neuróticos de resolução de conflito psíquico, conforme ocorre com o personagem, por exemplo, quando sente a necessidade premente de matar, o que lhe confere uma sensação de organização psíquica, e reforça seu sentimento de identidade. É desta maneira que Dexter se sente seguro dentro de seus limites egoicos.

Este seu comportamento compulsivo pode ainda ser ilustrado a partir da cena mencionada acima - da admoestação do pai quanto às pistas deixadas por Dexter. Podemos usá-la também como metáfora desta atuação. Para Winnicott (1960/1983), existe a pressuposição de que a mãe deve encontrar o bebê, isto é, acolher seu gesto espontâneo, estar disponível para reconhecer suas necessidades. Ao mesmo tempo, ela deve proteger a criança de possíveis invasões, deve preservar um espaço privado de sua subjetividade. $\mathrm{O}$ autor resume desse modo o paradoxo: a relação entre a mãe e o bebê é um “(...) sofisticado jogo de esconder em que é uma alegria estar escondido, mas um desastre não ser achado" (Winnicott, 1960/1983, p. 169). A partir daí, é possível pensar que a vivência de situações muito violentas no início da vida faz com que o bebê procure se esconder do adulto, não apenas nessas situações, mas em todas as outras, pois a criança busca a sensação de segurança, de que não pode ser invadida a qualquer momento. Podemos considerar então que o ritual de Dexter o preserva neste lugar de proteção em relação ao outro? Todos os cuidados para não deixar vestígios de seus crimes, sua postura permanentemente vigilante, sua desconfiança em relação às outras pessoas, além de uma forma de evitar a prisão, são também a construção de um abrigo, para que o outro não o alcance em seus conteúdos mais íntimos. Assim como precisou se esconder desse objeto primário invasivo nas origens, não pôde deixar pistas de si mesmo para que ele o encontrasse, Dexter parece mimetizar esse escondeesconde com a polícia, repetindo compulsivamente a certeza de que o outro não o alcançará.

Se é, então, a mãe quem deve imitar o seu bebê, reconhecendo os sinais de sua subjetividade, encontrando suas pistas, para dessa forma auxiliá-lo na metabolização das excitações que ela mesma deposita, levantamos a hipótese de que Dexter mata para impedir esse movimento, para não ser descoberto por esse objeto, cuja participação em sua vida primária fora tão traumática. Por outro lado, o bebê também quer ser encontrado pelo objeto bom, por alguém que cuide dele, que possa matizar suas pulsões. Desse modo, compreendemos melhor o que Winnicott (1960/1983) postula: é importante para o infante estar escondido, protegido da invasão violenta que pode advir do outro, mas é também trágico que este outro não seja capaz de resgatá-lo deste esconderijo, assegurando seu bem-estar a despeito dos afetos que perpassam esta relação. É, no fundo, o flagelo de estar sempre sozinho que leva o personagem a provocar no outro o desejo de encontrá-lo, pois ele quer ser encontrado, não pelo objeto mal, mas por aquele que finalmente poderá lhe acolher e garantir que ele esteja a salvo. Não seria este o jogo que Dexter empreende com a polícia, mantendo uma relação tão estreita com esta que deveria ser sua perseguidora?

Talvez, nessas situações em que o bebê não seja suficientemente bem encontrado, a perversão se instale em duas frentes: a tendência antissocial e a construção de um falso-self. Dexter parece representar o afeto - por exemplo, o seu namoro é sentido como 
teatral, assim como sua relação com a irmã: ele não sente de fato, mas representa que sente.

Temos agora todos os elementos para apresentar ao leitor as origens das escolhas inconscientes de Dexter que o levaram à perversão. Numa determinada ocasião, durante seu exercício profissional, Dexter se depara com uma cena criminal na qual havia enorme quantidade de sangue. Perturbado com esta visão, ele passa a ser invadido por lembranças recorrentes de um período anterior à sua adoção pelo casal Morgan. Dexter se vê, ainda bem pequeno, imerso em sangue, e muito assustado, chamando por sua mãe, que aparece na cena (temp. 1, ep. 10, 53:43 a 55:30) apenas para pedir que ele feche os olhos e não veja o que se passa naquele lugar. À medida que os episódios passam, descobrimos que aquela cena se refere ao assassinato de sua mãe biológica, Laura Moser, e de mais três pessoas, esquartejadas diante de duas crianças. Esse terrível massacre deixa marcas profundas no psiquismo delas: Brian, então com seis anos, é irmão mais velho de Dexter, e anos mais tarde acaba sendo internado em um hospital psiquiátrico por transtornos antissociais, de onde sai ao atingir a idade adulta. Dexter, que contava três anos na época do trauma, é acolhido e adotado pelo primeiro policial que chega à cena do crime, o detetive Harry Morgan. Apesar de terem seguido destinos muito diferentes, é interessante reparar que tanto Dexter quanto Brian reprisam a cena traumática no trabalho que exercem: o primeiro reconstrói a história de homicídios a partir de padrões de sangue encontrados, e o segundo fabrica próteses ortopédicas para pessoas que sofreram diversos tipos de amputação. No seriado, posteriormente Brian - que adota uma nova identidade, sob o nome de Rudy também se torna um assassino em série, e, sem poder contar com um código de conduta, mata pessoas que elege aleatoriamente, sobretudo prostitutas.

A cena do assassinato materno, que pode ser considerada o primeiro tempo do trauma, segundo o modelo winnicottiano proposto por Roussillon (1999), bombardeia o psiquismo do infante com enorme quantidade de excitação. Buscando dar um destino a essa energia, o aparelho psíquico da criança pode recorrer à alucinação do desejo, ao autoerotismo, ou à destrutividade. Mas, pelo caráter brutal da cena que descrevemos, percebemos que é pela via da violência que o sujeito poderá esboçar qualquer tentativa de escoamento. Portanto, durante sua infância, os episódios de crueldade com animais, a agressividade dirigida aos colegas de escola, e a tendência antissocial que o acometia, não teriam sido esforços do jovem Dexter, no sentido de efetuar uma ligação das reverberações desta experiência? É o que parece corroborar as hipóteses de Roussillon (2008) com relação à clínica dos adolescentes hiperviolentos que quebram tudo para não se quebrarem de raiva. Ponto fundamental, lembremos de passagem, para recusar a ideia de que a agressividade é uma “(...) expressão direta de uma "pulsão destrutiva"” (p. 182).

O segundo tempo do trauma pode ser atribuído à inabilidade de Harry em acolher estes comportamentos, interpretando-os como um pedido de ajuda do infante, que se mostra angustiado com a impossibilidade de representar tais conteúdos. Ainda que tenha procurado estar sempre próximo ao filho, orientando seu comportamento, protegendo-o da desconfiança dos outros, acreditamos que o pai adotivo de Dexter não respondeu satisfatoriamente à sua demanda, pois projetou sobre a personalidade do menino uma série de fantasias sádicas, as quais inundaram ainda mais seu psiquismo de excitações.

Consideramos que o terceiro tempo, que instala o traumatismo primário definitivamente, se relaciona à morte de Harry, quando Dexter, comprovando o abandono do objeto, vivencia uma clivagem no ego. Percebe-se que, diante disso, a saída que se configura é justamente a imitação deste movimento projetivo do adulto, que contribuiu para a formação da ferida narcísica do sujeito. Em certa medida, Dexter encena o papel do pai, ao imputar a violência e o prazer em exercê-la incessantemente a outros sujeitos, aos que se encaixam em seu código e devem ser punidos com a morte.

O caso Dexter mostra claramente como pode ser recusada a imagem comum, mesmo na literatura psicanalítica sobre o tema, de que não há sofrimento psíquico na perversão. As hipóteses metapsicológicas aqui levantadas sobre as origens da patologia mostram como a angústia do sujeito está presente desde o início do que será determinante para a saída perversa. É possível, por meio desse caso emblemático, elaborar estratégias clínicas para acolher o sujeito que optou consciente e inconscientemente pela violência perversa, oferecendo-lhe espaço para novas simbolizações e novas possibilidades subjetivas mais integradas ao laço social.

\section{REFERÊNCIAS}

Bonnet, G. (2008) La perversion: se venger pour survivre. Paris: Presses Universitaires de France.

Lindsay, J. (2004) Darkly Dreaming Dexter. New York City: Doubleday.

Manos Jr., J. (Director). (2006). Dexter: $1^{\text {a }}$ Temporada [DVD]. New York, NY: Showtime.

Rousillon, R. (2008) Le transitionnel, le sexuel et la réflexivité. Paris: Dunod.

Roussillon. R. (1999) Agonie, clivage et symbolization. Paris: Presses Universitaires de France. 
Roussillon. R. (2004) Narcissisme et "logiques" de la perversion. In R. Roussillon (2004). Narcissisme et perversion (pp. 115-166). Paris: Dunod.

Winnicott, D. W. (1983) Distorção do ego em termos de falso e verdadeiro self. In D. W. Winnicott (1960). O ambiente e os processos de maturação: estudos sobre a teoria do desenvolvimento emocional (pp. 128-139). Porto Alegre: Artes Médicas (Trabalho original publicado em 1960).
Winnicott, D. W. (2002) Agressão e suas raízes. In D. W. Winnicott (1939). Privação e delinquência (pp. 93110). São Paulo: Martins Fontes (Trabalho original publicado em 1939).

Recebido em 24-07-2012

Aceito em 28-11-2012
Endereço para correspondência:
Fábio Roberto Rodrigues Belo. Rua Germano Torres, 166, sala 707, Cruzeiro, CEP 30310-040, Belo Horizonte-MG, Brasil. E-mail: abiobelo76@gmail.com. 